\title{
Post-ICU discharge and outcome: rationale and methods of the The French and euRopean Outcome reGistry in Intensive Care Units (FROG-ICU) observational study
}

Alexandre Mebazaa ${ }^{1,2,3,4^{*}}$, Maria Chiara Casadio ${ }^{1,2,3}$, Elie Azoulay 5,6 , Bertrand Guidet ${ }^{7,8,9}$, Samir Jaber ${ }^{10}$, Bruno Levy ${ }^{11}$, Didier Payen ${ }^{1,3,12}$, Eric Vicaut ${ }^{2,3,13}$, Matthieu Resche-Rigon ${ }^{6,14}$ and Etienne Gayat ${ }^{1,2,3}$

\begin{abstract}
Background: Previous studies have demonstrated that ICU (intensive care unit) survivors have decreased long-term survival rates compared to the general population. However, knowledge about how to identify ICU survivors with higher risk of death and the adjustable factors associated with mortality is still lacking.

Methods and Design: The FROG-ICU (the French and European Outcome Registry in Intensive Care Units) study is a prospective, observational, multicenter cohort study where ICU survivors are followed up to one year after ICU discharge. Beside one year survival, the study is designed to assess incidence and identifying risk factors for mortality over the year following discharge from the ICU. All consecutive patients admitted in ICU to the 28 participating centers during the study period will be included. Every subject will undergo an evaluation at admission, throughout the ICU stay and at ICU discharge. The global, especially cardiovascular, assessment of each subject will be performed through a complete clinical exam, instrumental tests (electrocardiogram, echocardiogram) and biological parameters. Blood and urine samples will be collected at admission and at discharge with the primary goal to assess effectiveness of routine and novel cardiovascular, inflammatory and renal biomarkers, with potential interest in risk stratification for patients who survive an ICU stay. The follow up will include a careful tracking of patients through telephone calls and questionnaires at 3, 6 and 12 months after ICU discharge. FROG-ICU aims to identify the clinical and biological phenotype of patients with different levels of probability of death in the year after ICU discharge.

Discussion: FROG-ICU has been designed to better understand long term outcome after ICU discharge as well as risk factors for all-cause and cardiovascular morbidity and associated mortality. It is a large prospective multicenter cohort with a biological (on plasma and urine) collection and one-year follow-up of ICU patients. FROG ICU will allow performing a risk stratification of ICU survivors as to recognize the subset of patients who may benefit from an early intervention to allow decreased cardiovascular morbidity and related mortality.
\end{abstract}

Trial registration: ClinicalTrials.gov NCT01367093.

Keywords: Intensive care unit, Outcome, Mortality, Biomarkers

\footnotetext{
* Correspondence: alexandre.mebazaa@lrb.aphp.fr

'Department of Anesthesiology and Intensive Care, Saint Louis - Lariboisière

- Fernand Widal University Hospital, AP-HP, Paris, France

${ }^{2}$ INSERM UMR-S 942, Paris, France

Full list of author information is available at the end of the article
} 


\section{Background}

Numerous studies have been designed to investigate the early mortality of patients admitted in ICU. They focus on mortality at ICU discharge, at 28 days or/and at hospital discharge [1-3]. Case fatality is high, ranging from 14 to $44 \%[1,4-6]$ and up to $50 \%$ in septic shock patients $[7,8]$. Although many tools are available to assess the severity of illness and help clinicians to determine a prognosis during an ICU stay (Table 1), much less is known about what happens after ICU and hospital discharge.

To reduce the mortality rate of ICU survivors, it is important to identify the group of patients who have a higher probability of death in the year following ICU discharge and to recognize the adjustable factors associated with mortality. Few data have been published regarding the long-term outcome of ICU patients, and most importantly, there are no recommendations for the long-term management of these patients, only experts opinion have been published $[9,10]$. Some studies have demonstrated that mortality rates among ICU survivors are higher compared to the general population [11-15] and that ICU stay impact on patients' quality of life [16]. Moreover, other studies [14, 15] found that this over-risk of mortality rates is sustained over time persisting after 5 or 15 years of follow-up. Three studies [11-13] reported a worse survival rate for the ICU patients than that for the age-matched control population in the first year after ICU discharge, they also observed that after 2 to 4 years, the survival curves of the two groups became parallel.
Table 2 describes the 15 largest studies from the last 30 years, investigating the one-year outcome of ICU patients and their associated risk factors [11, 13, 15, 17-28]. Using these 15 studies, the pooled estimate of post-ICU one-year mortality rate was $18.8 \%$ (95\% confidence interval: 15.1 - $22.5 \%$ ), and the corresponding overall mortality (ICU + post-ICU one-year mortality) was 33.4 \% (95 \% CI: 27.0 - 39.9 \%). However, only six papers out of fifteen had a prospective and multicenter study design (most were post-hoc analyses of prospectively collected data) [11, 19, 20, 23-25]. As expected older age was always associated with long-term mortality, along with APACHE score at admission (or within the first $24 \mathrm{~h}$ of the ICU stay). Other factors associated with long-term mortality were the presence and type of comorbidities and the cause of ICU admission.

The association between some biomarker plasma levels and ICU mortality has been studied previously. Although it has been shown that troponin is frequently elevated in ICU patients (from 42.1 to $47.3 \%$ ) [29, 30], only $22.2-25.8 \%$ of those patients meet the diagnostic criteria for myocardial infarction. More importantly, elevated cTn during ICU stay was associated with an increased risk of ICU and hospital mortality (OR 2.53; $95 \%$ CI, 1.89 to 3.38) [31-36]. Natriuretic peptide (NPs) levels were also associated with patients' outcome. It has been demonstrated that brain natriuretic peptide (BNP) level can predict mortality at 6 months after hospital discharge for patients admitted with acute heart failure [37]. These results have been confirmed by other

Table 1 The severity of disease classification systems (or risk scores) most frequently used to evaluate the severity of ICU patients

\begin{tabular}{|c|c|c|c|c|}
\hline Score & Patients & Endpoint & Measure & Reference \\
\hline $\begin{array}{l}\text { Acute Physiolosy and Chronic } \\
\text { Health Evaluation (APACHE) }\end{array}$ & All ICU patients & Hospital mortality & $\begin{array}{l}\text { Within } 24 \text { h of ICU } \\
\text { admission }\end{array}$ & $\begin{array}{l}\text { Knauss WA, 1981, } 1985 \text { and } 1991 \\
\text { [67-69], Zimmerman JE } 2006 \text { [70] }\end{array}$ \\
\hline $\begin{array}{l}\text { Simplified Acute Physiology } \\
\text { Score (SAPS) }\end{array}$ & All ICU patients & 28-day mortality & $\begin{array}{l}\text { Once, at } 24 \mathrm{~h} \text { after ICU } \\
\text { admission }\end{array}$ & $\begin{array}{l}\text { Le Gall JR, } 1993 \text { [50] and Moreno RP } \\
2008 \text { [71] }\end{array}$ \\
\hline $\begin{array}{l}\text { Sequential Organ Failure } \\
\text { Assessment (SOFA) }\end{array}$ & All ICU patients & ICU mortality & Daily & Vincent JL, 1996 [51] \\
\hline $\begin{array}{l}\text { Multiple Organ Dysfunction } \\
\text { (MOD) score }\end{array}$ & All ICU patients & $\begin{array}{l}\text { ICU and hospital } \\
\text { mortality }\end{array}$ & Daily & Marshall J, 1995 [72] \\
\hline McCabe Classification & $\begin{array}{l}\text { Infective } \\
\text { patients }\end{array}$ & Hospital mortality & At admission & McCabe WR, 1962 [52] \\
\hline Sabadell Score & All ICU patients & Hospital mortality & At discharge & Fernandez R, 2006 [73] \\
\hline Glasgow Coma Scale (GCS) & $\begin{array}{l}\text { Traumatic brain } \\
\text { injury }\end{array}$ & $\begin{array}{l}\text { Quantify level of } \\
\text { consciousness }\end{array}$ & Daily & Teasdale GM, 1974 [53] \\
\hline $\begin{array}{l}\text { Confusion Assessment method } \\
\text { for the ICU CAM-ICU) }\end{array}$ & All ICU patients & Identify delirium & Daily & Ely EW, 2001 [54] \\
\hline Injury Severity Score (ISS) & Trauma patients & Hospital mortality & At admission & Baker SP, 1974 \\
\hline Trauma Score & Trauma patients & Hospital mortality & At admission & Champion HR, 1981 \\
\hline Lung Injury Score (Murray Score) & $\begin{array}{l}\text { Lung injured } \\
\text { patients }\end{array}$ & $\begin{array}{l}\text { Quantify the severity } \\
\text { of lung injury }\end{array}$ & Daily & Murray JF, 1988 \\
\hline
\end{tabular}


Table 2 The 15 largest studies including consecutive ICU patients, reporting one-year outcome and published in the last 30 years

\begin{tabular}{|c|c|c|c|c|c|c|c|c|c|c|c|}
\hline Name & Country & $\begin{array}{l}\text { Study } \\
\text { design }\end{array}$ & Recruitment period & $\begin{array}{l}\text { Sample } \\
\text { size }\end{array}$ & Age (years) & $\operatorname{Sex}(M \%)$ & Severity score & $\begin{array}{l}\text { ICU } \\
\text { mortality }\end{array}$ & $\begin{array}{l}\text { One-year mortality } \\
\text { after ICU discharge }\end{array}$ & $\begin{array}{l}\text { Overall } \\
\text { mortality }\end{array}$ & $\begin{array}{l}\text { Factors associated with } \\
\text { one-year mortality }\end{array}$ \\
\hline Zaren B, 1989 [12] & Sweden & $\mathrm{O} / \mathrm{P} / \mathrm{S}$ & 1983 & 978 & 53.6 & 58 & $N / R$ & $9.6 \%$ & $18.7 \%$ & $26.5 \%$ & $\begin{array}{l}\text { age, AC (cardiac arrest, MOF, } \\
\text { neurological or CV disease), } \\
\text { chronic condition (DM, } \\
\text { CHF, cortisone medication) }\end{array}$ \\
\hline Dragsted L, 1989 [13] & Denmark & $\mathrm{O} / \mathrm{P} / \mathrm{S}$ & 1979-1983 & 1308 & 60 & 50.6 & $N / R$ & $18.3 \%$ & $29.8 \%$ & $42.7 \%$ & $\begin{array}{l}\text { Age, gender, medical } \\
\text { admission category, cancer }\end{array}$ \\
\hline Rochwood K 1993 [14] & Canada & $\mathrm{O} / \mathrm{P} / \mathrm{M}$ & $N / R$ & 884 & $N / R$ & 63.2 & 18.8.(APACHE II) & $14.4 \%$ & $23.5 \%$ & 34.5 & Age \\
\hline Niskanen M, 1996 [53] & Finland & $\mathrm{O} / \mathrm{P} / \mathrm{M}$ & 1987 & 12180 & 57.2 & 62.9 & 11.7 (APACHE II) & $9.9 \%$ & $20 \%$ & $27.9 \%$ & $\begin{array}{l}\text { Age, gender, emergency } \\
\text { admission, APACHE II at } \\
\text { admission, cancer, CV dz, } \\
\text { RF, Gl dz, cardiac arrest }\end{array}$ \\
\hline Douglas C, 2002 [15] & USA & $\mathrm{O} / \mathrm{P} / \mathrm{M}$ & Feb 1997 - Mar 1999 & 538 & 65.8 & 56.3 & $N / R$ & $47.4 \%^{\mathrm{a}}$ & $32.5 \%$ & $64.5 \%$ & $N / R$ \\
\hline Keenan SP, 2002 [16] & Canada & $\mathrm{O} / \mathrm{R} / \mathrm{M}$ & Apr 1994- Mar 1996 & 27103 & 54.3 & 57.1 & $N / R$ & $14.3 \%^{\mathrm{a}}$ & $10.9 \%^{\mathrm{b}}$ & $N / R$ & $\begin{array}{l}\text { Age, comorbidity } \\
\text { (lymphoma/leukemia, } \\
\text { HIV, RF) }\end{array}$ \\
\hline Kaarlola A, 2003 [17] & Finland & $\mathrm{O} / \mathrm{P} / \mathrm{S}$ & 1995 & 591 & $N / R$ & $N / R$ & $N / R$ & $N / R$ & $N / R$ & $36 \%$ & $N / R$ \\
\hline Wright JC, 2003 [9] & UK & $\mathrm{O} / \mathrm{R} / \mathrm{S}$ & Jul 1985- Jul 1992 & 2104 & 53.6 & $N / R$ & 14 (APACHE II) & 20.6 & 20.2 & $36.7 \%$ & $\begin{array}{l}\text { Age, APACHE II, AC } \\
\text { (hematological and } \\
\text { neurological dz, septic shock) }\end{array}$ \\
\hline Bagshaw SM, 2006 [18] & Canada & $\mathrm{O} / \mathrm{P} / \mathrm{M}$ & May 1999 - May 2002 & 5693 & 64.9 & 62 & 24.9 (APACHE II) & $13.4 \%$ & $12.9 \%$ & $24.5 \%$ & $\begin{array}{l}\text { Age, medical diagnosis } \\
\text { at admission, APACHE ॥ } \\
\text { score, AKI }\end{array}$ \\
\hline Williams TA 2008 [11] & Australia & $\mathrm{O} / \mathrm{P} / \mathrm{S}$ & $1987-2002$ & 22298 & 61 & 67 & 11 (APACHE ॥) & $10.7 \%^{\mathrm{a}}$ & $5.4 \%$ & $15.5 \%$ & $\begin{array}{l}\text { Age, comorbidity, AC, new } \\
\text { diagnosted cancer }\end{array}$ \\
\hline Orwelius L, 2010 [19] & Sweden & $\mathrm{O} / \mathrm{P} / \mathrm{M}$ & Aug 2000- Jun 2004 & 2586 & $N / R$ & $N / R$ & $N / R$ & $10.2 \%$ & $24 \%$ & $31.4 \%$ & $N / R$ \\
\hline Braun A, 2012 [20] & USA & $\mathrm{O} / \mathrm{P} / \mathrm{M}$ & Nov 1997 - Apr 2009 & 51815 & 61.7 & 58.2 & $N / R$ & $13 \%^{\mathrm{a}}$ & $15.3 \%$ & $26.3 \%$ & $\begin{array}{l}\text { Low preadmission } 25(\mathrm{OH}) \mathrm{D} \\
\text { level }\end{array}$ \\
\hline Meynaar IA, 2012 [21] & Holland & $\mathrm{O} / \mathrm{R} / \mathrm{S}$ & Jan 2004 - Dec 2009 & 3477 & $N / R$ & $N / R$ & $N / R$ & $8.2 \%$ & $20.1 \%$ & $26.7 \%$ & $\begin{array}{l}\text { Age, APACHE II, discharge } \\
\text { not toward home }\end{array}$ \\
\hline Grander W, 2013 [22] & Austria & $\mathrm{O} / \mathrm{P} / \mathrm{S}$ & Jan 2001- Jun 2004 & 1086 & $N / R$ & $N / R$ & $N / R$ & $9.3 \%$ & $15.7 \%^{b}$ & $N / R$ & HR before ICU discharge \\
\hline Luangasanatip N, 2013 [23] & Thailand & $\mathrm{O} / \mathrm{R} / \mathrm{S}$ & Jan 2004 - Dec 2005 & 10321 & 57.6 & $N / R$ & $N / R$ & $31.5 \%$ & $20.7 \%$ & $45.7 \%$ & $\begin{array}{l}\text { AC (cerebrovascular dz, } \\
\text { cancer) }\end{array}$ \\
\hline FROG ICU & Europe & $\mathrm{O} / \mathrm{P} / \mathrm{M}$ & $\begin{array}{l}\text { From Apr } 2011 \text { to } \\
\text { Dec } 2013\end{array}$ & $\begin{array}{l}2250 \\
\text { (expected) }\end{array}$ & & & & & & & \\
\hline
\end{tabular}

ICU intensive care unit, $O$ observational, $R$ retrospective, $P$ prospective, $S$ single-center, $M$ multi-center, $N / R$ not reported, $C P R$ cardiopulmonary resuscitation, $A K I$ acute kidney injury, WBCC white blood cells count, $A C$ admission category, MOF multi organ failure, DM diabetes mellitus, $C H F$ chronic heart failure, $d z$ disease, $C V$ cardiovascular, $R F$ respiratory failure, $G l$ gastrointestinal, 25(OH)D 25-idrossicolecalciferolo, HR heart rate aHospital mortality (ICU mortality was not available)

${ }^{\mathrm{b}}$ Mortality rate was extrapolated from a Kaplan-Meier curve 
investigators in heart failure patients admitted to the ICU [38]. High BNP levels are also associated with 30day mortality in septic shock patients [39, 40]. Similarly, biomarker of inflammation and renal function have been shown to be associated with mid- and long-term outcome [41-47].

Thus, measuring cardiovascular, inflammatory and/or renal biomarkers at ICU discharge could be useful in early recognition of high risk patients in whom potential preventive or curative strategies could improve outcomes. Furthermore measuring biomarkers at discharge may allow risk stratification of patients for whom close clinical monitoring as well as chronic life-saving treatments should be introduced. For instance, implementation of oral beta-blocker at ICU discharge has proven benefits in acute heart failure patients who were admitted to the ICU for inotropic treatment (dobutamine or levosimendan) and who received oral beta-blocker therapy at discharge [48]. This has been confirmed on survival at one year after discharge in ICU patients admitted for acute respiratory failure [49].

Here, we describe the design of the French and euRopean Outcome reGistry in Intensive Care Unit (FROG-ICU), the main objective of which is to assess the incidence and identify the risk factors of mortality during the year following discharge from the ICU. This identification of the risks will be based on the patients' evaluations throughout their ICU stays, using clinical and "routine" biological parameters (including creatinine, sodium, potassium, hemoglobin, etc....) as well as ICU severity score systems that are already being used to assess short-term mortality as described in Table 1 . In addition, the effectiveness of novel cardiovascular biomarkers, including highly sensitive troponin, natriuretic peptides, sST2 and adrenomedullin (Table 3 ) to early assess adjustable factors associated with long term mortality will be evaluated.

\section{Methods and Design Study design}

The French and European Outcome Registry in Intensive Care Units (FROG ICU) study is a prospective, observational, multicenter cohort study, designed to assess the incidence and to identify the risk factors of mortality during the year following discharge from the ICU. The study will be conducted in France and in Belgium in accordance with Good Clinical Practice, Declaration of Helsinki 2002, validated by the ethical committee (Comité de Protection des Personnes - Ile de France IV, IRB n00003835. Comission d'éthique biomédicale hospitalo-facultaire de l'hôpital de Louvain, IRB $\left.n^{\circ} \mathrm{B} 403201213352\right)$ and was registed on ClinicalTrials.gov (NCT01367093). The study consists of two phases (Fig. 1): initially, all patients admitted to any of the participating centers during the recruitment period will be screened for the eligibility criteria listed below; subsequently, all patients included in the study who survive to ICU discharge will be followed up for one year through a telephone call and postal questionnaires at 3, 6 and 12 months.

\section{Participants}

The study will involve 28 medical, surgical or mixed ICUs in 19 hospitals. The study cohort will include all consecutive patients who are admitted in ICU to any of the participating centers during the recruitment period when the following inclusion criteria are met: invasive mechanical ventilation support for at least $24 \mathrm{~h}$ and/or treatment with a positive inotropic agent (except dopamine) for more than $24 \mathrm{~h}$. Because the ethical committee waived the need for written consent, all patients and/or next of kin will be informed and will orally consent to participate; consent was documented in the medical record by the investigator. Exclusion criteria are the following: less than 18 years old; severe head injury (initial Glasgow Coma Scale $<8$ ) or brain death or a persistent vegetative state; pregnancy or breastfeeding; transplantation in the past 12 months; not expected to survive or to leave the hospital; and/or no social security coverage.

\section{Duration of the study and number of participating centers}

The duration of participation for a patient will be a maximum of 12 months after ICU discharge. The inclusion period for any center is 32 months, and we hypothesize that the average number of patients to be recruited in each center would be 10 per month. The total study duration is 44 months.

\section{Study objectives \\ Primary objective}

The primary purpose of this study is to assess the incidence of all-cause mortality in the year following an ICU stay and to identify the factors associated with mortality; those factors include both the clinical-biological factors and the ICU risk scores.

\section{Secondary objectives}

The secondary objectives of this study are: 1) to determine the incidence and the risk factors of cardiovascular morbidity and mortality in the year following an ICU stay; 2) to evaluate quality of life in the year following an ICU stay; 3) to assess the role of novel biomarkers in assessing long-term outcome after ICU discharge (Table 3). 
Table 3 Cardiovascular, inflammatory and renal biomarkers of potential interest in predicting long-term mortality in critically ill patients

\begin{tabular}{|c|c|c|c|}
\hline Name & Function & Clinical interest & References \\
\hline \multicolumn{4}{|l|}{ Cardio-vascular biomarkers } \\
\hline copeptine & $\begin{array}{l}\text { Peptide of stress deriving from } \\
\text { vasopressine }\end{array}$ & marker of cardiovascular disease & Khan SQ, 2007 \\
\hline Proenkephalin & endogenous opiod polypeptide hormon & $\begin{array}{l}\text { marker of cardiovascular and } \\
\text { cerebrovascular disease }\end{array}$ & Seizinger BR, 1985 \\
\hline Troponin I us & $\begin{array}{l}\text { part of troponin complex, heart } \\
\text { contraction }\end{array}$ & marker of myocyte injury & Labugger R, 2000 \\
\hline Troponine T hs & $\begin{array}{l}\text { part of troponin complex, heart } \\
\text { contraction }\end{array}$ & marker of myocyte injury & Labugger R, 2000 \\
\hline Brian natriuretic peptide (BNP) & $\begin{array}{l}\text { increase of natriuresis and decrease of } \\
\text { vasculare resistance }\end{array}$ & marker of myocyte stress & Davidson NC, 1994 \\
\hline N-terminal pro-BNP (NT-proBNP) & biologically inactive segment of BNP & marker of myocyte stress & Moe GW, 2007 \\
\hline adrenomedullin (ADM) & $\begin{array}{l}\text { vasodilatation, induction of angiogenesis, } \\
\text { protection against oxydative stress and } \\
\text { hypoxic injury }\end{array}$ & marker of myocyte stress & Khan SQ, 2007 \\
\hline Soluble ST2 & $\begin{array}{l}\text { involved in cardiac remodeling and } \\
\text { fibrosis }\end{array}$ & marker of myocyte stress & Shah RV, 2010 \\
\hline galectine 3 & $\begin{array}{l}\text { involved in inflammation, fibrosis and } \\
\text { neoplastic transformation }\end{array}$ & marker of heart failure & de Boer RA, 2009 \\
\hline \multicolumn{4}{|l|}{$\begin{array}{l}\text { Biomarkers of infection and/or } \\
\text { inflammation }\end{array}$} \\
\hline C-reactive protrine (CRP) & acute-phase protein & marker of inflammation/infection & Elster SK, 1956 \\
\hline Interleukine 6 & $\begin{array}{l}\text { pro-inflammation and anti-inflammation } \\
\text { cytokine }\end{array}$ & marker of inflammation/infection & Castell JV, 1990 \\
\hline procalcitonin $(\mathrm{PCT})$ & precursor of calcitonin & marker of infection, mostly bacterial & Jones AE, 2007 \\
\hline \multicolumn{4}{|l|}{ Renal biomarkers } \\
\hline Plasmatic cystatin C & $\begin{array}{l}\text { protein derived by all nucleated cells, } \\
\text { readsorbed by proximal tubular cells }\end{array}$ & $\begin{array}{l}\text { marker of decrease glomerular } \\
\text { filtration rate }\end{array}$ & Roos JF, 2007 \\
\hline Urinary cystatin $C$ & $\begin{array}{l}\text { protein derived by all nucleated cells, } \\
\text { readsorbed by proximal tubular cells }\end{array}$ & marker of renal tubular injury & Roos JF, 2007 \\
\hline $\begin{array}{l}\text { Plasmatic and urinary neutrophil } \\
\text { gelatinase associated lipocain (NGAL) }\end{array}$ & involve in innate immunity & marker of renal tubular injury & Kjeldsen L 1993 \\
\hline
\end{tabular}

\section{Data collection and biological samples}

For each patient included, an electronic case report form will be completed that documents relevant information about the ICU stay and the one-year follow-up period. At the time of inclusion, the following will be collected: demographics, data on past medical history, ICU admitting diagnosis, hemodynamic (non-invasive and invasive) and respiratory parameters, severity of disease classification systems (SAPS-II, SOFA, CAM-ICU, McCabe Classification and GCS) [50-54]; digital electrocardiogram (EKG), recorded with CarTouch (Cardionics S.A., Bruxelles, Belgium), a high-definition electrocardiograph provided with TeleTouch software for the automatic transfer of the EKG to the informatics system. Routine laboratory tests will be performed. In 9 ICUs, an echocardiogram will also be performed within a few hours of inclusion. During the first 3 days of each ICU stay, respiratory and cardiovascular parameters (including hemodynamic and EKG) will be recorded daily and subsequently twice a week; SOFA score will be performed the first 3 days after inclusion, and routine biomarkers will be measured according to physician practice. Renal replacement therapy, death and cause of death in ICU will be collected.

The following data will be collected at ICU discharge: clinical parameters, digital EKG and routine biological assessment, ICU length of stay, duration of mechanical ventilation, SOFA score, treatment and results of echocardiogram at discharge when performed.

All patients included in the study population who survive to ICU discharge will be followed up for one additional year or until death, except for severely disabled subjects (Glasgow Outcome Scale $<4$ at discharge). Oneyear outcome will be evaluated through data collection at 3, 6 and 12 months after ICU discharge. At those time points, patients will be contacted by telephone, and 


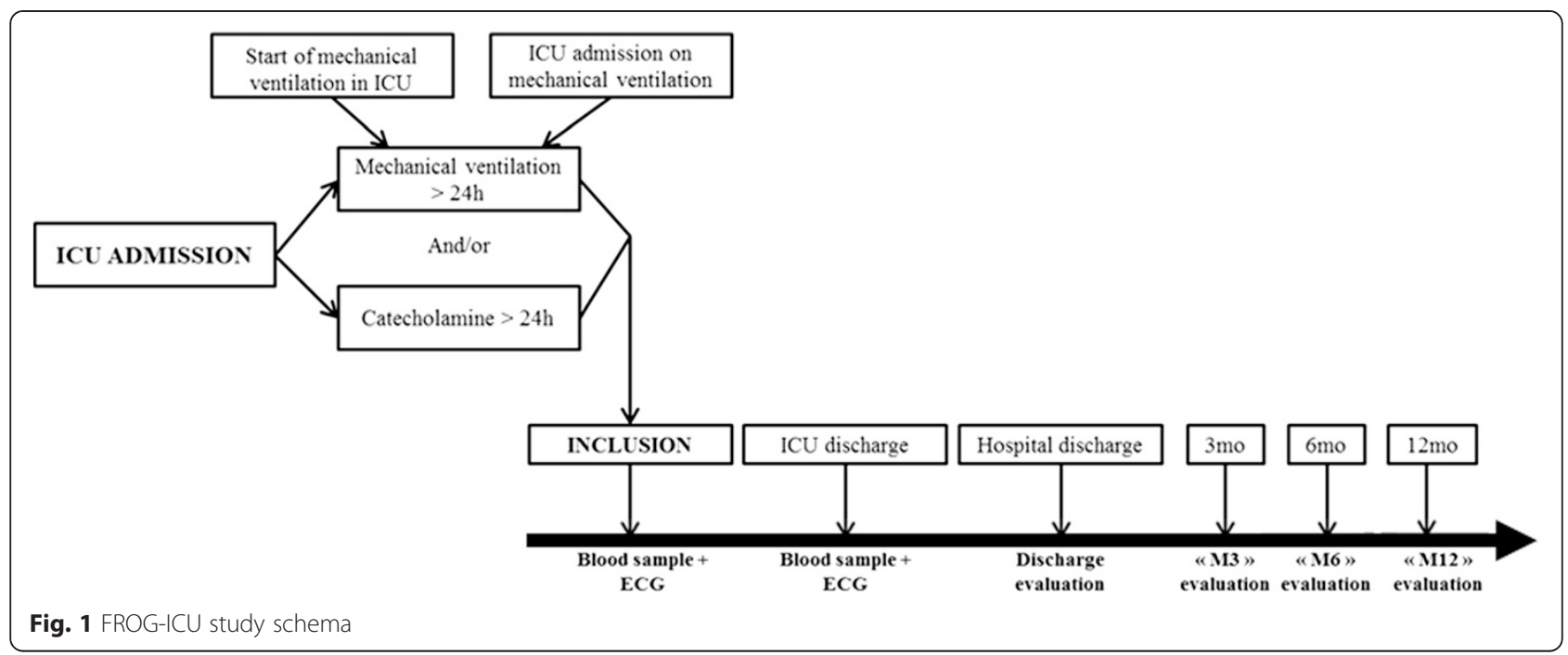

information about vital status (patient dead or alive), rehospitalization, and cardiovascular morbidity will be recorded. For patients lost of follow-up, the vital status will eventually be checked through the national health services records when available. In addition, 4 follow-up questionnaires will be submitted to the study population: the Hospitalization Anxiety and Depression Scale (HADS) [55] and the Short Form-36 (SF-36) [56, 57] at discharge and at 3, 6, and 12 months after and the Impact of Event Scale-Revised (IES-R) [58] at 3, 6 and 12 months; a social questionnaire for assessing patients' social environments (actual occupation, resumption of activity, level of income, marital status,...) will be submitted at 3 months after discharge.

A biological collection will be created with blood (3x10 $\mathrm{ml}$ in EDTA and aprotinin) and urine $(10 \mathrm{ml})$ samples collected at two different time points: admission and discharge. The biological collection will allow for the measurement of novel biomarkers in a central laboratory. Table 3 lists the biomarkers with potential interest for the risk stratification of patient who survive an ICU stay.

\section{Statistical analysis}

Primary analysis will be performed on all patients included in the cohort. Only patients who withdrew consent will be excluded. Patients who decided to stop tracking or who were lost to follow-up will be included in the analysis. Any missing value will be replaced by the previous value (the last value carried forward method). Sensitivity analyses for missing values will be conducted, for example, using a multiple imputation (MICE, multiple imputation by chained equations [59]. All tests will be bilateral formulation, with a risk of type I error of $5 \%$.
Calculating the number of subjects required is based on the primary endpoint, i.e., the impact and the risk factors on one year all-cause mortality. The study of the literature and the completion of the preliminary inquiry (conducted in December 2009) in 14 centers that participated to the study conduct us to assume a 1-year mortality after ICU discharge of $18 \%$. To ensure detection with a power of $80 \%$ of binary prognostic factors with a prevalence of $33 \%$ and an expected OR of 1.5 and a probability of death of approximately $18 \%, 1636$ patients should be included in this study [60]. Assuming a rate of refusal and/or follow-up losses of $10 \%$, the number of patients to be included in the one-year follow-up amounts to 1800 . The expected in-ICU mortality rate is $25 \%$. Thus, taking into account these results, the number of patients to be included is 2250 .

The primary analysis will be based on the research of the determinants of 1-year mortality of patients included in the FROG-ICU (i.e., ICU patients who needed mechanical ventilation for more than $24 \mathrm{~h}$ and/or treatment with a positive inotropic agent over 24 and who were discharged alive from the ICU) among clinical and biological variables and biomarkers of common interest (i.e., troponins, natriuretic peptides). The regression model used will be the logistic model. The log-linearity of the quantitative variables will be systematically evaluated, and, if appropriate, variable transformations will be performed. A selection model process will be performed using stepwise selection method. The selection process model will be further validated by bootstrap [61]. The existence of any collinearities will be observed, and a test of goodness of fit will be performed using the test and the van Cessie Houwelingen method [62]. Finally a cross-validation procedure will be performed. The measures of association will be provided, with odds ratios and confidence intervals at $95 \%$. An estimate of related 
risks will also be conducted. Finally, the overall incidence of 1-year mortality will be estimated at a confidence interval of $95 \%$.

As it is now recognized that highlighting the statistically significant association between new biomarkers and patient outcomes is not sufficient to demonstrate the interest of these biomarkers in terms of risk prediction [63-65]. We will use the proposed methodology of Pencina et al., which has been used in multiple articles of application. For each biomarker of interest, the net reclassification improvement (NRI) and integrated discrimination improvement (IDI) will be calculated, and comparisons between different biomarkers will be performed [64].

Regarding quality of life, a strategy similar to that outlined for the 1-year mortality analysis will be used to assess its impact and to highlight the predictors of impaired QoL at 6 months or 1 year. QoL will be estimated using the SF-36 score (ranging from 0 to 100) [66]. Altered QoL is considered when SF-36 is lower than 50. In addition, the value of the SF-36 measured in the FROG ICU study will be compared with the values that are typically found in healthy populations of the same age and sex. Interaction between quality of life and social life will be assessed by using information from the social questionnaire.

Last, regarding stress and anxiety, as previously described, IES-R higher than 30 will define post-traumatic stress disorder [58] and HADS higher than 8 will defined anxiety [55]. Similarly, analyses will consist in seeking to identify risk factors of stress and anxiety after ICU discharge.

\section{Discussion}

Very limited information is currently available concerning the risk factors for long-term survival after a stay in the ICU. Some studies have investigated the long-term prognosis of ICU patients [11, 13, 15, 17-28], but only a few of them have been properly designed to achieve this result, in a prospective, multicenter manner and using a large number of patients $[11,19,20,23-25]$. Few studies have evaluated biological parameters [25-27] as factors associated with long-term mortality, and only one study has correlated the patient's condition at discharge with the long-term risk of death [27]. Consequently, at the moment, there are neither guidelines nor recommendations to assist clinicians in providing optimal patient management after ICU.

Accordingly, FROG-ICU is an innovative study that reflects the endeavor of many ICU physicians to assess the incidence of all-cause mortality in the year after ICU discharge and to identify the factors associated with this mortality. The strengths of the present study are listed in Table 4: first is the study design because FROG-ICU
Table 4 Strengths of the present study

\begin{tabular}{ll}
\hline Strengths of FROG-ICU study \\
\hline Study design & $\begin{array}{l}\text { Observational, non-interventional, prospective } \\
\text { and multicenter cohort study }\end{array}$ \\
$\begin{array}{l}\text { Methods for the } \\
\text { evaluation of the patient }\end{array}$ & $\begin{array}{l}\text { Complete clinical assessment, instrumental } \\
\text { tests (electrocardiogram, echocardiogram), } \\
\text { biological parameters and routine } \\
\text { biomarkers during ICU stay }\end{array}$ \\
Constitution of a biobank & $\begin{array}{l}\text { For each patient, plasma and urine will be } \\
\text { collected. For ICU-survivor, urine and plasma } \\
\text { at discharge will also be collected }\end{array}$ \\
$\begin{array}{l}\text { Repeated evaluations of } \\
\text { the patient }\end{array}$ & $\begin{array}{l}\text { At admission, during the ICU stay, at } \\
\text { discharge and during one year }\end{array}$ \\
\hline
\end{tabular}

is a large observational, prospective and multicenter cohort study; second, the evaluation of each patient is performed through a comprehensive clinical assessment, instrumental tests (electrocardiogram, echocardiogram) and biological parameters; finally, all of the data are collected at admission, during the stay and at discharge.

Preliminary studies suggest that pre-discharge therapy, especially the oral administration of beta-blockers, may improve the survival after an ICU stay [48, 49]. This would be confirm or not using the FROG-ICU data notably by using causal inference approaches. Moreover all of these findings favor developing a clinical trial with inclusion criteria and number of patients to be recruited based on the present study, with the main purpose of decreasing long-term all-cause and particularly cardiovascular morbidity and mortality after ICU discharge.

To sum up, FROG-ICU has been designed to better understand long term outcome after ICU discharge as well as risk factors for all-cause and cardiovascular morbidity and associated mortality. Because it is a large prospective multicenter study that collects clinical, biological and focused cardiovascular biomarkers, FROG ICU will allow to perform a risk stratification of ICU survivors as to recognize the subset of patients who may benefit from an early intervention to allow decreased cardiovascular morbidity and related mortality. Should the cardiovascular risks be identified here and validated in a sub-cohort, a randomized controlled trial using the results of this risk stratification will be in order to demonstrate survival benefits from a pre- and post-discharge multifaceted intervention that will include close cardiovascular monitoring and oral cardio-vascular therapies.

\section{Competing interests}

The authors declare that they have no competing interests.

\section{Authors' contributions}

AM is the principal investigator of FROG ICU. EG, EV and MRR are the methodologist/biostatistician of the study. MC was responsible for the systematic review of the literature and for the writing of the protocol. EA, $\mathrm{BG}, \mathrm{SJ}, \mathrm{BL}$ and $\mathrm{DP}$ are all members of the steering committee and all have edited the present manuscript. All authors read and approved the final manuscript. 


\section{Acknowledgements}

The authors would like to acknowledge the great work of Marie-Céline Fournier, the head nurse coordinating the study and all RCA involved in each center. They also thank all the research team of the URC Lariboisière Fernand Widal, including Véronique Jouis and Sophie Gérard and Pauline Cavelier, the heard CRA of the DRCD.

FROG ICU study was supported by grants from Assistance PubliqueHôpitaux de Paris (AOR01004) and from Société Française d Anesthésie Réanimation.

\section{Author details}

${ }^{1}$ Department of Anesthesiology and Intensive Care, Saint Louis - Lariboisière - Fernand Widal University Hospital, AP-HP, Paris, France. ${ }^{2}$ INSERM UMR-S 942, Paris, France. ${ }^{3}$ Department of Anesthesiology and Critical Care Medicine, Saint Louis - Lariboisière University Hospital, University Paris Diderot, UMR-S 942, INSERM, 2 rue Ambroise Paré, 75010 Paris, France. ${ }^{4}$ DHU Neurovasculaire, Paris, France. ${ }^{5}$ Medical intensive care, Saint Louis Lariboisière - Fernand Widal University Hospital, AP-HP, Paris, France. ${ }^{6}$ INSERM UMR-S 717, Paris, France. ${ }^{7}$ Medical intensive care, Saint Antoine University Hospital, AP-HP, Paris, France. ${ }^{8}$ INSERM UMR 1136, Paris, France. ${ }^{9}$ University Paris VI, Paris, France. ${ }^{10}$ Surgical Intensive Care, Saint Eloi University Hospital, Montpellier, France. ${ }^{11}$ Medical intensive care, CHU Nancy - Hôpital Brabois Adultes, Vandœuvre-les-Nancy, France. ${ }^{12}$ INSERM UMR-S 1160, Paris, France. ${ }^{13}$ Unité de Recherche Clinique, Saint Louis - Lariboisière - Fernand Widal University Hospital, AP-HP, Paris, France. ${ }^{14}$ Service de Biostatistique et d'Informatique Médicale, Saint Louis - Lariboisière - Fernand Widal University Hospital, AP-HP, Paris, France.

Received: 7 November 2014 Accepted: 6 October 2015

Published online: 12 October 2015

\section{References}

1. Turnbull AD, Carlon G, Baron R, Sichel W, Young C, Howland W. The inverse relationship between cost and survival in the critically ill cancer patient. Crit Care Med. 1979:7(1):20-3.

2. Spagnolo SV, Hershberg PI, Zimmerman HJ. Medical intensive care unit. Mortality rate experience in large teaching hospital. N Y State J Med. 1973;73(6):754-7

3. Dowdy DW, Eid MP, Sedrakyan A, Mendez-Tellez PA, Pronovost PJ, Herridge MS, et al. Quality of life in adult survivors of critical illness: a systematic review of the literature. Intensive Care Med. 2005;31(5):611-20.

4. Harrison DA, Brady AR, Rowan K. Case mix, outcome and length of stay for admissions to adult, general critical care units in England, Wales and Northern Ireland: the intensive care national audit \& research centre case Mix programme database. Crit Care. 2004;8(2):R99-111.

5. Boumendil A, Angus DC, Guitonneau AL, Menn AM, Ginsburg C, Takun K, et al. Variability of intensive care admission decisions for the very elderly. PLoS One. 2012;7(4), e34387.

6. Boumendil A, Latouche A, Guidet B. On the benefit of intensive care for very old patients. Arch Intern Med. 2011;171(12):1116-7.

7. Brun-Buisson C, Doyon F, Carlet J, Dellamonica P, Gouin F, Lepoutre A, et al. Incidence, risk factors, and outcome of severe sepsis and septic shock in adults. A multicenter prospective study in intensive care units. French ICU Group for Severe Sepsis. JAMA. 1995;274(12):968-74.

8. Friedman G, Silva E, Vincent JL. Has the mortality of septic shock changed with time. Crit Care Med. 1998;26(12):2078-86.

9. Desai SV, Law TJ, Needham DM. Long-term complications of critical care. Crit Care Med. 2011;39(2):371-9.

10. Needham DM, Davidson J, Cohen H, Hopkins RO, Weinert C, Wunsch H, et al. Improving long-term outcomes after discharge from intensive care unit: report from a stakeholders' conference. Crit Care Med. 2012;40(2):502-9.

11. Niskanen M, Kari A, Halonen P. Five-year survival after intensive carecomparison of 12,180 patients with the general population. Finnish ICU Study Group. Crit Care Med. 1996;24(12):1962-7.

12. Flaatten $H$, Kvale R. Survival and quality of life 12 years after ICU. A comparison with the general Norwegian population. Intensive Care Med. 2001;27(6):1005-11.

13. Wright JC, Plenderleith $L$, Ridley SA. Long-term survival following intensive care: subgroup analysis and comparison with the general population. Anaesthesia. 2003;58(7):637-42.
14. Cuthbertson BH, Rattray J, Campbell MK, Gager M, Roughton S, Smith A, et al. The PRaCTICaL study of nurse led, intensive care follow-up programmes for improving long term outcomes from critical illness: a pragmatic randomised controlled trial. BMJ. 2009;339:b3723.

15. Williams TA, Dobb GJ, Finn JC, Knuiman MW, Geelhoed E, Lee KY, et al Determinants of long-term survival after intensive care. Crit Care Med. 2008;36(5):1523-30.

16. Hofhuis JG, Spronk PE, van Stel HF, Schrijvers GJ, Rommes JH, Bakker J. The impact of critical illness on perceived health-related quality of life during ICU treatment, hospital stay, and after hospital discharge: a long-term follow-up study. Chest. 2008;133(2):377-85.

17. Zaren B, Bergstrom R. Survival of intensive care patients. I: Prognostic factors from the patient's medical history. Acta Anaesthesiol Scand. 1988;32(2):93-100.

18. Dragsted L, Qvist J. Outcome from intensive care. III. A 5-year study of 1308 patients: activity levels. Eur J Anaesthesiol. 1989;6(5):385-96.

19. Rockwood K, Noseworthy TW, Gibney RT, Konopad E, Shustack A, Stollery D, et al. One-year outcome of elderly and young patients admitted to intensive care units. Crit Care Med. 1993;21(5):687-91.

20. Douglas SL, Daly BJ, Gordon N, Brennan PF. Survival and quality of life: short-term versus long-term ventilator patients. Crit Care Med. 2002;30(12):2655-62.

21. Keenan SP, Dodek P, Chan K, Hogg RS, Craib KJ, Anis AH, et al. Intensive care unit admission has minimal impact on long-term mortality. Crit Care Med. 2002;30(3):501-7.

22. Kaarlola A, Pettila V, Kekki P. Quality of life six years after intensive care. Intensive Care Med. 2003;29(8):1294-9.

23. Bagshaw SM, Mortis G, Doig CJ, Godinez-Luna T, Fick GH, Laupland KB. Oneyear mortality in critically ill patients by severity of kidney dysfunction: a population-based assessment. Am J Kidney Dis. 2006;48(3):402-9.

24. Orwelius L, Nordlund A, Nordlund P, Simonsson E, Backman C, Samuelsson A, et al. Pre-existing disease: the most important factor for health related quality of life long-term after critical illness: a prospective, longitudinal, multicentre trial. Crit Care. 2010;14(2):R67.

25. Braun A, Chang D, Mahadevappa K, Gibbons FK, Liu Y, Giovannucci E, et al. Association of low serum 25-hydroxyvitamin D levels and mortality in the critically ill. Crit Care Med. 2011;39(4):671-7.

26. Meynaar IA, Van Den Boogaard M, Tangkau PL, Dawson L, Sleeswijk Visser S, Bakker J. Long-term survival after ICU treatment. Minerva Anestesiol. 2012;78(12):1324-32.

27. Grander W, Mullauer K, Koller B, Tilg H, Dunser M. Heart rate before ICU discharge: a simple and readily available predictor of short- and long-term mortality from critical illness. Clin Res Cardiol. 2013;102(8):599-606.

28. Luangasanatip N, Hongsuwan M, Lubell Y, Limmathurotsakul D, Teparrukkul $P$, Chaowarat $S$, et al. Long-term survival after intensive care unit discharge in Thailand: a retrospective study. Crit Care. 2013;17(5):R219.

29. Lim W, Qushmaq I, Cook DJ, Crowther MA, Heels-Ansdell D, Devereaux PJ. Elevated troponin and myocardial infarction in the intensive care unit: a prospective study. Crit Care. 2005;9(6):R636-44

30. Lim W, Cook DJ, Griffith LE, Crowther MA, Devereaux PJ. Elevated cardiac troponin levels in critically ill patients: prevalence, incidence, and outcomes. Am J Crit Care. 2006;15(3):280-8. quiz 9.

31. Martin M, Mullenix P, Rhee P, Belzberg H, Demetriades D, Salim A. Troponin increases in the critically injured patient: mechanical trauma or physiologic stress? J Trauma. 2005;59(5):1086-91.

32. Quenot JP, Le Teuff G, Quantin C, Doise JM, Abrahamowicz M, Masson D, et al. Myocardial injury in critically ill patients: relation to increased cardiac troponin I and hospital mortality. Chest. 2005;128(4):2758-64.

33. King DA, Codish S, Novack V, Barski L, Almog Y. The role of cardiac troponin I as a prognosticator in critically ill medical patients: a prospective observational cohort study. Crit Care. 2005;9(4):R390-5.

34. Landesberg G, Vesselov Y, Einav S, Goodman S, Sprung CL, Weissman C. Myocardial ischemia, cardiac troponin, and long-term survival of highcardiac risk critically ill intensive care unit patients. Crit Care Med. 2005;33(6):1281-7.

35. Wu TT, Yuan A, Chen CY, Chen WJ, Luh KT, Kuo SH, et al. Cardiac troponin I levels are a risk factor for mortality and multiple organ failure in noncardiac critically ill patients and have an additive effect to the APACHE II score in outcome prediction. Shock. 2004;22(2):95-101.

36. Baillard C, Boussarsar M, Fosse JP, Girou E, Le Toumelin P, Cracco C, et al. Cardiac troponin I in patients with severe exacerbation of chronic obstructive pulmonary disease. Intensive Care Med. 2003;29(4):584-9. 
37. Logeart D, Thabut G, Jourdain P, Chavelas C, Beyne P, Beauvais F, et al. Predischarge B-type natriuretic peptide assay for identifying patients at high risk of re-admission after decompensated heart failure. J Am Coll Cardiol. 2004;43(4):635-41.

38. Cohen-Solal A, Logeart D, Huang B, Cai D, Nieminen MS, Mebazaa A. Lowered B-type natriuretic peptide in response to levosimendan or dobutamine treatment is associated with improved survival in patients with severe acutely decompensated heart failure. J Am Coll Cardiol. 2009;53(25):2343-8.

39. Ueda S, Nishio K, Akai Y, Fukushima H, Ueyama T, Kawai Y, et al. Prognostic value of increased plasma levels of brain natriuretic peptide in patients with septic shock. Shock. 2006;26(2):134-9.

40. Post F, Weilemann LS, Messow CM, Sinning C, Munzel T. B-type natriuretic peptide as a marker for sepsis-induced myocardial depression in intensive care patients. Crit Care Med. 2008;36(11):3030-7.

41. Ridker PM, Danielson E, Fonseca FA, Genest J, Gotto Jr AM, Kastelein JJ, et al. Reduction in C-reactive protein and LDL cholesterol and cardiovascular event rates after initiation of rosuvastatin: a prospective study of the JUPITER trial. Lancet. 2009;373(9670):1175-82.

42. Reichlin T, Potocki M, Breidthardt T, Noveanu M, Hartwiger S, Burri E, et al. Diagnostic and prognostic value of uric acid in patients with acute dyspnea. Am J Med. 2009;122(11):1054. e7- e14.

43. Vandal K, Rouleau P, Boivin A, Ryckman C, Talbot M, Tessier PA. Blockade of S100A8 and S100A9 suppresses neutrophil migration in response to lipopolysaccharide. J Immunol. 2003;171(5):2602-9.

44. Ehlermann P, Eggers K, Bierhaus A, Most P, Weichenhan D, Greten J, et al. Increased proinflammatory endothelial response to S100A8/A9 after preactivation through advanced glycation end products. Cardiovasc Diabetol. 2006;5:6.

45. Boyd JH, Kan B, Roberts H, Wang Y, Walley KR. S100A8 and S100A9 mediate endotoxin-induced cardiomyocyte dysfunction via the receptor for advanced glycation end products. Circ Res. 2008;102(10):1239-46.

46. Vogl T, Tenbrock K, Ludwig S, Leukert N, Ehrhardt C, van Zoelen MA, et al. Mrp8 and Mrp14 are endogenous activators of Toll-like receptor 4, promoting lethal, endotoxin-induced shock. Nat Med. 2007;13(9):1042-9.

47. Potocki M, Breidthardt $T$, Reichlin $T$, Morgenthaler NG, Bergmann A, Noveanu M, et al. Midregional pro-adrenomedullin in addition to b-type natriuretic peptides in the risk stratification of patients with acute dyspnea: an observational study. Crit Care. 2009;13(4):R122.

48. Mebazaa A, Nieminen MS, Filippatos GS, Cleland JG, Salon JE, Thakkar R, et al. Levosimendan vs. dobutamine: outcomes for acute heart failure patients on beta-blockers in SURVIVE. Eur J Heart Fail. 2009;11(3):304-11.

49. Noveanu M, Breidthardt T, Reichlin T, Gayat E, Potocki M, Pargger H, et al. Effect of oral beta-blocker on short and long-term mortality in patients with acute respiratory failure: results from the BASEL-II-ICU study. Crit Care. 2010;14(6):R198.

50. Le Gall JR, Lemeshow S, Saulnier F. A new simplified acute physiology score (SAPS II) based on a European/North American multicenter study. JAMA. 1993;270(24):2957-63.

51. Vincent JL, Moreno R, Takala J, Willatts S, De Mendonca A, Bruining H, et al. The SOFA (sepsis-related organ failure assessment) score to describe organ dysfunction/failure. On behalf of the working group on sepsis-related problems of the European Society of intensive care medicine. Intensive Care Med. 1996;22(7):707-10.

52. McCabe WRJG. Gram negative bacteremia: I. Etiology and ecology. Arch Intern Med. 1962;110:845-7.

53. Teasdale $G$, Jennett B. Assessment of coma and impaired consciousness. A practical scale. Lancet. 1974;2(7872):81-4.

54. Ely EW, Margolin R, Francis J, May L, Truman B, Dittus R, et al. Evaluation of delirium in critically ill patients: validation of the Confusion Assessment Method for the Intensive Care Unit (CAM-ICU). Crit Care Med. 2001;29(7):1370-9.

55. Zigmond AS, Snaith RP. The hospital anxiety and depression scale. Acta Psychiatr Scand. 1983;67(6):361-70.

56. Ware Jr JE, Sherbourne CD. The MOS 36-item short-form health survey (SF-36). I. Conceptual framework and item selection. Med Care. 1992;30(6):473-83.

57. Brazier JE, Harper R, Jones NM, O'Cathain A, Thomas KJ, Usherwood T, et al. Validating the SF-36 health survey questionnaire: new outcome measure for primary care. BMJ. 1992;305(6846):160-4

58. Brunet A, St-Hilaire A, Jehel L, King S. Validation of a French version of the impact of event scale-revised. Can J Psychiatry. 2003;48(1):56-61.
59. Van Buuren S, Groothuis-Oudshoorn K. mice: Multivariate Imputation by Chained Equations in R. J Stat Softw. 2011;45(3):1-67.

60. Hsieh FY, Bloch DA, Larsen MD. A simple method of sample size calculation for linear and logistic regression. Stat Med. 1998;17(14):1623-34.

61. Harrell Jr FE, Lee KL, Mark DB. Multivariable prognostic models: issues in developing models, evaluating assumptions and adequacy, and measuring and reducing errors. Stat Med. 1996;15(4):361-87.

62. le Cessie $\mathrm{S}$, van Houwelingen HC. Testing the fit of a regression model via score tests in random effects models. Biometrics. 1995;51(2):600-14.

63. Hlatky MA, Greenland P, Arnett DK, Ballantyne CM, Criqui MH, Elkind MS, et al. Criteria for evaluation of novel markers of cardiovascular risk: a scientific statement from the American Heart Association. Circulation. 2009;119(17):2408-16.

64. Pencina MJ, D'Agostino Sr RB, D'Agostino Jr RB, Vasan RS. Evaluating the added predictive ability of a new marker: from area under the ROC curve to reclassification and beyond. Stat Med. 2008;27(2):157-72. discussion 207-12.

65. Cook NR. Use and misuse of the receiver operating characteristic curve in risk prediction. Circulation. 2007;115(7):928-35.

66. Perneger TV, Leplege A, Etter JF, Rougemont A. Validation of a Frenchlanguage version of the MOS 36-Item Short Form Health Survey (SF-36) in young healthy adults. J Clin Epidemiol. 1995;48(8):1051-60.

67. Knaus WA, Zimmerman JE, Wagner DP, Draper EA, Lawrence DE. APACHEacute physiology and chronic health evaluation: a physiologically based classification system. Crit Care Med. 1981;9(8):591-7.

68. Knaus WA, Wagner DP, Draper EA, Zimmerman JE, Bergner M, Bastos PG, et al. The APACHE III prognostic system. Risk prediction of hospital mortality for critically ill hospitalized adults. Chest. 1991;100(6):1619-36.

69. Knaus WA, Draper EA, Wagner DP, Zimmerman JE. APACHE II: a severity of disease classification system. Crit Care Med. 1985;13(10):818-29.

70. Zimmerman JE, Kramer AA, McNair DS, Malila FM. Acute Physiology and Chronic Health Evaluation (APACHE) IV: hospital mortality assessment for today's critically ill patients. Crit Care Med. 2006;34(5):1297-310.

71. Moreno RP, Metnitz PG, Metnitz B, Bauer P, Afonso de Carvalho S, Hoechtl A. Modeling in-hospital patient survival during the first 28 days after intensive care unit admission: a prognostic model for clinical trials in general critically ill patients. J Crit Care. 2008;23(3):339-48.

72. Marshall JC, Cook DJ, Christou NV, Bernard GR, Sprung CL, Sibbald WJ. Multiple organ dysfunction score: a reliable descriptor of a complex clinical outcome. Crit Care Med. 1995;23(10):1638-52.

73. Fernandez R, Baigorri F, Navarro G, Artigas A. A modified McCabe score for stratification of patients after intensive care unit discharge: the Sabadell score. Crit Care. 2006;10(6):R179.

\section{Submit your next manuscript to BioMed Central and take full advantage of:}

- Convenient online submission

- Thorough peer review

- No space constraints or color figure charges

- Immediate publication on acceptance

- Inclusion in PubMed, CAS, Scopus and Google Scholar

- Research which is freely available for redistribution 